\title{
Numbers of Taiga Bean Geese Anser $f$. fabalis utilizing the western and central flyways through Sweden during springtime 2007-2015
}

\author{
Antalet tajgasädgäss Anser f. fabalis som nyttjade den västra och centrala \\ flyttvägen genom Sverige våren 2007-2015
}

\author{
ULF SKYLLBERG
}

\begin{abstract}
Bean Geese Anser fabalis were counted at all known spring staging sites in south-central Sweden within the time window when geese migrating along the western and central flyways had left their wintering grounds in Denmark and southernmost Sweden, but before they had crossed the Bothnian Bay to Finland. Reliable counts were obtained for seven years 2007-2015: 57000 in 2007, 55500 in 2008, 49300 in 2009, 46900 in 2011, 47400 in 2012, 53900 in 2014, and 60200 in 2015. The increase between 2011 and 2015 was significant and may be related to recently decreased hunting pressure in Finland. Subtraction of an estimated 4000 Tundra Bean

Geese Anser f. rossicus and addition of two small populations of Taiga Bean Geese Anser f. fabalis wintering in the UK and in NW Jutland that were likely missed in the counts, yielded a total estimate of 44 200-57 500 Taiga Bean Geese utilizing the western and central flyways. Based on these counts, combined with data on geese wintering east of the Baltic Sea, I estimate the world population to 68000 Taiga Bean Geese in 2015.

Ulf Skyllberg, Brännavägen 38, SE-90788 Umeå, Sweden; e-mail: ulf.skyllberg@sek.slu.se
\end{abstract}

Received 26 February 2015, Accepted 28 October 2015, Editor: R. Ekblom

\section{Introduction}

The Taiga Bean Goose Anser f. fabalis breeds in the taiga zone from Scandinavia to central Russia. The most recent world population estimate reported in the literature (Fox et al., 2010) is 63000 individuals. This estimate was stated to be based on mid-winter counts, but no data were reported. Two years later, in 2012, Wetlands International reported a world population of only $40000-45000$ individuals (http:// wpe.wetlands.org), but without providing any published results supporting this estimate. Because the global population of the Taiga Bean Goose is small and believed to have been declining since the 1990s, when it was estimated to comprise 90 000-110 000 individuals (Nilsson et al. 1999), AEWA (Agreement on the Conservation of African-Eurasian Migratory Waterbirds, http://www.unep-aewa.org) recently upgraded the subspecies from a Column B, category 1 to a Column A, category $3 \mathrm{c}$ population. As a consequence, AEWA in 2013 launched an action plan for the Taiga Bean Goose to quantify and take measures to counteract the population decline. At top of the AEWA agenda for monitoring actions is the need to provide improved estimates of the size of the global population, as well as of sub-popula- tions of the Taiga Bean Goose.

In recent decades, the main wintering area of the Taiga Bean Goose has been southernmost Sweden and Denmark (Nilsson et al. 1999, Nilsson 2013). It is well-established from observations of colourmarked individuals that Bean Geese breeding in Finland migrate along the central flyway (Figure 1) through south-central Sweden in spring and autumn (Nilsson \& Pirkola 1991, 1999, Pessa et al. 2004, Nilsson 2011). Birds using the western flyway along the Bothnian Bay (Figure 1), linking staging sites in south-central and northern Sweden (Skyllberg et al. 2008, 2009), breed in northernmost Scandinavia and NW Finnish Lapland, as corroborated by data from colour-marking and satellite tracking (Nilsson et al. 2010). Recent satellite and colour-marking schemes further demonstrate that a group of up to 400 Taiga Bean Geese wintering in Scotland migrates via Denmark, southern Norway and south-west Sweden to their breeding grounds in the county of Dalarna in Sweden (http://scotlandsbeangeese.wikispaces.com). Finally there are two seemingly distinct groups of Taiga Bean Geese wintering in northern Jutland. One group comprising approximately 1200 birds (Nordjyllands 


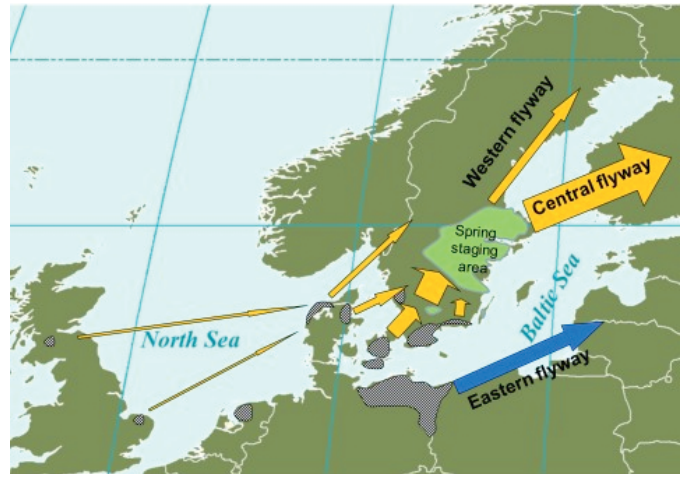

Figure 1. Wintering grounds (grey hatched), flyways (arrows) and the spring staging area in south-central Sweden (light green) where the counts reported in this study were conducted.

Övervintringsområden (gråstreckade), flyttvägar (pilar) och vårrastområdet $i$ centrala delar av södra Sverige (ljus grönt) där räkningarna från denna studie utfördes.

Fugle 2013, 2014) winters in NW Jutland, and is indicated to breed mainly in west-central Sweden and across the border into Norway (Parslow-Otsu 1991, J. E. Østnes, pers. comm.). Another group of approximately 1500 birds winters in NE Jutland (Nordjyllands Fugle 2013, 2014) and recent marking reveals that it migrates along the western flyway through Sweden to breeding grounds in northernmost Fennoscandia (O. Therkildsen, pers comm.).

Taiga Bean Goose counts of the longest standing (1977-2011) are autumn (October and November) and mid-winter (January) counts conducted in Sweden (Nilsson 2013). There is substantial amongyear variability in these records, as demonstrated by the five-year average of the October counts in Sweden: 52 300, 46400 and 61500 in the periods of 1997-2001, 2002-2006 and 2007-2011, respectively (Nilsson 2013). The variation may partly be due to fluctuations in the size of the population, but other factors may also be involved. The counts are restricted to only one country (Sweden) and the dates for the counts are set in advance. Depending on the weather conditions and timing of migration, a variable proportion of the population may either not have reached Sweden (during October counts), or many geese may already have left the country during cold spells (during November and January counts). Another factor to consider when evaluating autumn counts is the effect of wind drift during southbound migration. Because mass-migration of Bean Geese during autumn regularly takes place in connection with the passage of cold front systems and strong tailwinds, small variations in wind direction between the NE and NW sectors may result in shifts of the migration routes of the Taiga, as well as of the Tundra Bean Goose Anser f. rossicus, in east-west direction. In particular the influx to Sweden of Tundra Bean Geese belonging to the large ( $>600000$, Fox et al. 2010) population that normally migrate east of the Baltic Sea, may vary considerably among years. The inclusion of Tundra Bean Geese in the Swedish autumn counts of Bean Geese has recently been recognized as a source of variability among years, especially in October (Kampe-Persson 2011, Heinicke \& de Jong 2013).

There are several arguments for spring counts in south-central Sweden to represent more robust estimates of Taiga Bean Goose populations migrating west of the Baltic Sea than autumn counts. The most important advantage is that the vast majority of the Taiga Bean Geese wintering in southernmost Sweden and Denmark, and following the western and central flyways to their breeding grounds, during a short time-window (lasting for about one to several weeks, depending on weather conditions) are concentrated to a restricted geographical area in south-central Sweden.

Following the methodology outlined in Skyllberg and Tjernberg (2008), systematic spring counts were conducted covering 44 major and a number of minor sites during the period 2007-2015. Two of these years (2010 and 2013) did not provide good enough conditions for a reliable count. Here data for the counts in the years 2007, 2008, 2009, 2011, 2012, 2014 and 2015 are reported. After correction for the inclusion of an estimated number of Tundra Bean Geese, and for the relatively few birds remaining at their wintering grounds in Sweden and Denmark and birds already reaching Norway and Finland, the reported counts are suggested to provide a robust estimate of the population(-s) of Taiga Bean Geese utilizing the western and central flyways through Sweden.

\section{Materials and methods}

\section{Staging sites and counts}

Bean Geese were counted at 44 major staging sites (Figure 2) during spring 2007-2015. At 42 of the sites Bean Geese were counted at feeding grounds, and at two sites (No. 2, Östen and No. 21, Tåkern) the geese were counted in early morning during their flight from night roosts to the feeding grounds. Counts at sites Östen and Tåkern have a 
Figure 2. The 44 staging sites at which spring counts were conducted. In Appendix 1 the name of the sites and the number of Bean Geese counted are listed for each year. The larger symbols of No. 2 (Lake Östen), No. 4 (Lake Kvismaren), No. 21 (Lake Tåkern) and No. 28 (Skåraområdet) indicate counts of more than 2000 geese at least six of the seven years.

De 44 rastplaster där vårräkningar utfördes. I Appendix 1 återfinns namnen på platserna och antalet sädgäss som räknades varje år. Större symboler för $n r .2$ (Östen), $n r .4$ (Kvismaren), nr. 21 (Tåkern) och $n r$ 28 (Skåraområdet) indikerar räkningar överskridande 2000 gäss åtminstone sex av de sju åren.

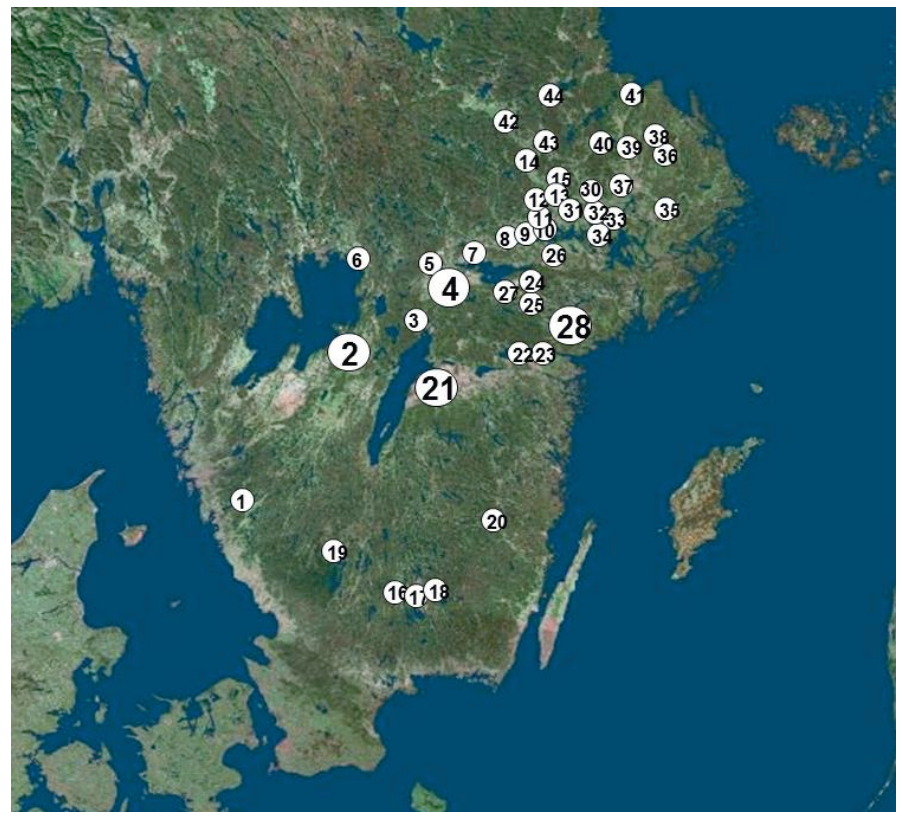

history of several decades and were conducted on weekend days involving tens of people to cover the complete flight of geese from several roost sites in these lakes. Each site had one appointed coordinator, who was in charge of and summarized the counts conducted by several counters. At most of the sites the same persons were acting as coordinators and counters all seven years. At sites hosting less than 500-1000 geese, counts were commonly conducted by only one person with many years of experience of counting Bean Geese at that particular site. In addition to the 44 major sites, there were a number of sites normally hosting between $\sim 20$ and 200 geese that were summarized for each county. Like the major sites, these sites were all wellknown for decades to host staging Bean Geese but in small and highly variable numbers among years. At maximum, these small staging sites summed up by county contributed $8 \%$ of the total count (2012) but most years less than 5\% (Appendix 1). The site fidelity of Bean Geese is well-known and during the nine years period of this study maximum five sites hosting more than 50 Bean Geese, at which there were no historic records of the species, were identified. Thus, the error related to Bean Geese overlooked at historically non-recognized sites is considered very small and negligible in relation to other uncertainties in the counts.

To get a reliable estimate of the complete western and central flyway populations, all sites were counted during a limited time window when the Bean Geese had left their wintering grounds in Denmark and Sweden, but before they had left Sweden for Finland. To ensure this was the case, personal contacts at wintering grounds in Jutland and the UK and at spring staging sites in Finland were complemented by observations made by numerous ornithologists and reported at the web-based bird observation systems of the Nordic countries: Denmark (www.dofbasen.dk), Norway (www.artsobservasjoner.no/fugle), Sweden (www.artportalen. se) and Finland (www.tiira.fi). In Figure 3 data from the county of Skåne (wintering ground), Uppland (staging sites in the northern part of the area in Figure 2) and Finland are illustrated for the year 2015. When the count was conducted (6-7 March) only 80 Bean Geese remained in Skåne and the first 300 had reached SW Finland (in the area of Pori where the first sightings are made every year of birds taking the leap over the Bothnian Bay from Sweden). Note that the number given for Skåne (and Denmark) represents the maximum number of Bean Geese (corrected for multiple reports of the same geese) reported at or after the count date in spring. This is to ensure that possible overlooked groups of birds still lingering at wintering sites were included in the spring count. Similarly, data from Finland and Norway always involved the maximum count (corrected for multiple reports of the same birds) at or prior to the count date. Data 


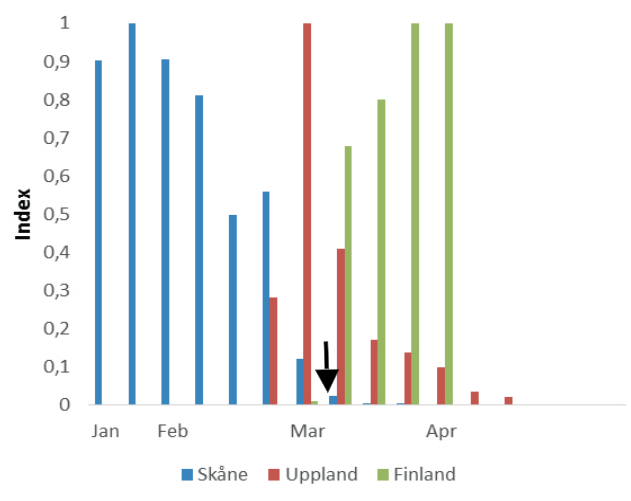

Figure 3. Weekly reports of Bean Geese in 2015 from the counties of Skåne (wintering grounds in south Sweden) and Uppland (spring staging sites), taken form the Swedish Species Observation System (www.artportalen.se), and from the Finnish Bird Observation System (www.tiira.fi). For Skåne and Uppland observations from the third week of January to the fourth week of April are included and for Finland from the third week of January to the first week of April. For simplicity all reported observations were summed (and thus not corrected for double-counts) for 7-day periods and then divided by the largest sum of any of the weeks to yield an index from 0 to 1 . The coordinated count at Swedish staging sites was conducted 6-7 March (black arrow) when all but 80 Bean Geese had left Skåne and 300 had reached Finland (Table 1).

Veckorapporter för sädgäss 2015 från Skåne och Uppland, tagna från rapportsystemet Artportalen, samt från Finland från det finska rapportsystemet. För Skåne och Uppland inkluderas rapporter från sista veckan av januari till fjärde veckan av april och för Finland från tredje veckan av januari till första veckan av April. Rapporterna är summerade (utan korrigering för dubbelräkningar) i 7-dagars perioder och sedan dividerade med den högsta veckosumman för att ge ett index mellan 0 och 1. Den koordinerade räkningen utfördes 6-7 mars (svart pil) då samtliga förutom 80 sädgäss hade lämnat Skåne och 300 hade nått Finland (Tabell 1).

Given for Denmark in Table 1 represents the sum of Bean Geese observed in mainly NW Jutland and Bean Geese reported from Norway were observed in the southernmost part of the country.

In order to avoid overlooking birds in active migrating between sites and to avoid double-counting of geese at multiple sites, it was important to select dates for counting when the turnover of geese at staging sites was at a minimum. This was achieved by selecting a period for the count with unfavourable weather conditions for active migration. The size of the spring staging area in south-central Sweden (Figure 1) is small enough to be affected by the same weather system, with some time delay in wind directions and precipitation, which are the two most important weather factors controlling migration. The timing of weather systems creating SW tail-wind conditions ahead of incoming low-pressure systems from the Atlantic Ocean at intervals of approximately 4-7 days in principal dictates the maximum pace of migration waves of birds in spring. It is known from observations along the western flyway of neck-banded geese and by daily counts and information based on the fidelity of typical flocks of geese using a particular area, that the average length-of-stay is typically around 7-10 days, but occasionally up to two weeks or more (e.g. Skyllberg et al. 2013). Further, Bean Geese migrating along the western flyway typically utilize the westernmost staging sites (mainly No. 2 Östen and No. 4 Kvismaren) in south-central Sweden and stay longer at these sites than geese migrating along the central flyway. This is related to the earlier snowmelt at sites situated along the cost in SW Finland, as compared to the corresponding sites in E central Sweden. Because of this the central flyway to Finland is activated on average 7-10 days prior to the western flyway north of the flyway divide in the counties of Västmanland and Uppland (Figure 1; Skyllberg et al. 2009). Some marked geese are known to combine a stop in the southern range with another stop at a site in the northern part of the staging area in Figure 1, while other individuals only use one major spring stop in south-central Sweden any given year.

Based on the above information, a strategy was adopted where counts were conducted under unfavourable wind conditions, at least two and maximum four days after a significant migration event, when the geese were destined to stay and feed. The methodology obviously demands a large flexibility when to make the count. To ensure this, close contact was kept between the author and all coordinators, typically every second day to be able to decide when to conduct the count. The absence of active migration of Bean Geese (as well as other daytime migrating large birds like geese, swans and cranes) was verified by observations reported on the Swedish Internet-based Species Observation system (www.artportalen.se). This system is highly utilized by ornithologists and for the purpose of identifying days with and without bird migration during early springtime, when many ornithologists are active, this method can be considered highly reliable. All years the majority of sites were counted the same day, in the morning. However, because some sites could not be covered that day, the total time period for the counts varied between two days (2014 and 2015) and five days (2007). As a gen- 
eral rule to avoid double counts, if no data were available at the major day of counting, dates of counts at sites in the southern range of the staging area (most often site No. 2 Östen and site No. 21 Tåkern, which both were limited to counts during weekends) were always later in time than counts at sites further north. In the years 2010 and 2013 the weather conditions resulted in a very late but rapid snow-melt. This caused a smearing out effect with substantial numbers of Bean Geese remaining at the wintering grounds in Denmark and Sweden, at the same time as substantial numbers already reached the spring staging sites in Finland. Consequently, no reliable counts could be reported for these two years.

\section{Statistical errors and testing}

To be able to make a statistical comparison of counts among years, the total error (standard deviation, $\sigma_{\text {Total }}$ ) of the counts in Sweden was propagated from estimates of major uncertainties by equation (1). Errors $(\sigma)$ where expressed as fractions (i.e. 0.15 for $\pm 15 \%$ error) and coefficients $a$ - $d$ denote the weighing of each error term by the actual numbers counted each year.

$$
\begin{aligned}
\sigma_{\text {Total }}^{2}= & \text { Square-root }\left(a^{2} \sigma_{\text {Tåkern_östen }}^{2}+b^{2} \sigma_{\text {Other_sites }}^{2}\right. \\
& \left.+c^{2} \sigma_{\text {Tundra_bean_goose }}^{2}+d^{2} \sigma_{\text {Double_counts }}^{2}\right)
\end{aligned}
$$

The error of the morning flight counts at Tåkern and Östen, caused by incorrect assignment to species (possible inclusion of Greylag Goose and to a smaller extent Greater White-fronted Goose) and difficulty of locating and quantifying flying birds, is estimated to $\pm 15 \%$ at each of these two sites. At all other sites geese were counted at feeding grounds. The counting error at these sites is estimated at $\pm 3 \%$. Because of closer observation distances of stationary flocks that could be more easily counted, the uncertainty is expected to be much lower than for morning flight counts. At many sites relatively stable numbers were obtained 4-5 days around the count date and typically a site was counted several days to improve the precision of the estimate. It can also be expected that possible systematic errors (over- or underestimates) related to personal differences among counters, partly would cancel out when counts for all sites are summed up. The expected variability in counts among years caused by variability in the number of Tundra Bean Geese was accounted for by adding an estimated average number of this sub-species and an error term of \pm
$20 \%$. Finally an estimated error due overestimates by double-counting of birds at multiple sites and underestimates by overlooking Bean Geese at unknown feeding grounds or staging sites is included. These two latter errors are expected to partly cancel out and therefore the sum of them $\left(\sigma_{\text {Double count }}\right)$ is expected to be small on a relative scale $( \pm 5 \%)$.

A statistical (Chi-square) test was performed to demonstrate if the variations in counts among years simply were due to uncertainties in the counts or if there were any significant changes in the number of geese during the study period. Let $Y_{i}(t)$ represent the number of birds counted at a specific site (i) and year $(t)$. The total sum of counts $S(t)$ is then calculated as $S(t)=Y_{l}(t)+\ldots+Y_{N}(t)$. The number $(N)$ of sites is regarded to be large enough and independent of each other for the sum $S(t)$ to be approximately normally distributed, according to the Central limit theorem. This means that also the quotient $(S(t)-\mu(t)) / \sigma(t)$ is approximately normally distributed $\mathrm{N}(0,1)$, where $\mu(t)$ is the expected number of birds at year $t$ and $\sigma(t)$ the standard deviation for the total count the same year. If quotients determined for different years $t_{1}, t_{2}, \ldots t_{M}$ are independent of each other the sum (2):

$$
\sum_{i=1}^{M}\left(\frac{S\left(t_{i}\right)-\mu\left(t_{i}\right)}{\sigma\left(t_{i}\right)}\right)
$$

is Chi-square $\left(\chi^{2}\right)$ distributed with $M$ degrees of freedom. When tested for possible differences among years the expected count $\mu(t)$ was set to the average count for the seven years of this study. Post hoc pairwise comparisons of the quotient $(S(t)$ - $\mu(t)) / \sigma(t)$ between years were then performed with count averages of 2007-2008, 2009-2012 and 2014-2015 set to represent expected numbers of birds for individual years belonging to each of the three time intervals, using a Bonferroni correction to avoid committing a Type I error. Two quotients differing more than $\sqrt{2} / 2.33=3.3$ are considered significantly different $(\mathrm{p}<0.05)$, Samuels et al. 2014.

\section{Results and discussion}

\section{Total counts of the western and central flyway} populations of Bean Geese

In Table 1 counts of Swedish staging areas, as well as staging areas in Finland and Norway and geese remaining at wintering sites in Denmark and 
Table 1. Counted Bean Geese Anser fabalis at spring staging sites in Sweden and data reported from Finland, Norway and wintering sites in Sweden (Skåne) and Denmark taken from national web-sites for bird reporting. Antal räknade sädgäss Anser fabalis på vårrastlokaler i Sverige samt data från Finland, Norge och övervintringsplatser i Sverige (Skåne) och Danmark från nationella web-baserade rapportsystem.

\begin{tabular}{lrrrrrrr}
\hline Year Ar & 2007 & 2008 & 2009 & 2011 & 2012 & 2014 & 2015 \\
Date Datum & $17-21.3$ & $3-10.3$ & $20-22.3$ & $25-27.3$ & $16-18.3$ & $7-8.3$ & $6-7.3$ \\
\hline Staging sites & & & & & & & \\
Rastplatser & & & & & & & \\
Sweden & 54980 & 54475 & 48355 & 46650 & 45110 & 50065 & 59675 \\
Finland & 1570 & 70 & 55 & 0 & 1700 & 3300 & 300 \\
Norway & 10 & 10 & 20 & 30 & 180 & 200 & 40 \\
\hline Wintering sites & & & & & & & \\
Vinterlokaler & 350 & 150 & 800 & 150 & 405 & 120 & 120 \\
Denmark & 50 & 700 & 50 & 100 & 0 & 170 & 80 \\
Sweden & 56960 & 55405 & 49280 & 46930 & 47395 & 53855 & 60215 \\
\hline Total & & & & & & &
\end{tabular}

southernmost Sweden (the county of Skåne) are summarized. The overall trend of the total count was a decline from a higher level in 2007 and 2008 (57000 and 55400 , respectively) to a lower level of 46 900-49 300 geese in 2009-2012, and then finally an increase to 53900 in 2014 and 60200 in 2015 .

Counts of individual sites each year are given in Appendix 1. At the dates of counts, the estimated number of Bean Geese remaining at wintering

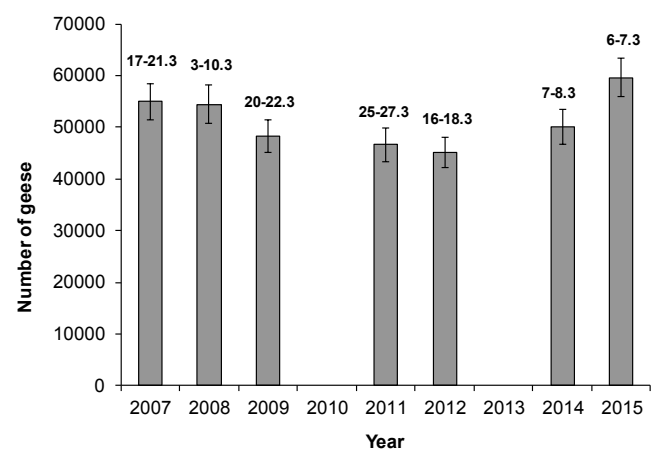

Figure 4. Number of Bean Geese A. fabalis counted at the Swedish spring staging sites 2007-2015. The dates of the count are noted above each bar. Because of difficult conditions the years 2010 and 2013, the sum of counts those years were uncertain and therefore not reported. Error bars were calculated by equation (1).

Antalet sädgäss A. fabalis räknade på svenska vårrastningslokaler 2007-2015. Datum för räkningarna är noterade över respektive stapel. På grund av sämre betingelser åren 2010 och 2013 blev räkningarna dessa år osäkra och de rapporteras därför inte. Felstaplarna beräknades $i$ enlighet med ekvation (1). grounds in Sweden and Denmark varied between $0.3 \%$ (2016) and $1.7 \%$ (2009) of the total counts. The proportion of geese reaching SW Finland (Pori area) was less than $0.2 \%$ four of the years and $2.7 \%$ in $2007,3.5 \%$ in 2012 and $6.1 \%$ in 2014 (Table 1).

In Figure 4 counts at Swedish spring staging sites are illustrated with error bars calculated by equation (1). The estimated error varied between a minimum of \pm 2900 (2012) and a maximum of \pm 3600 (2008 and 2015), corresponding to 6-7.5 $\%$ of the total counts each year. Double-counts and possibly overlooked flocks, were estimated as the major uncertainty, contributing to $53-69 \%$ of the variance. The estimated uncertainties for counts of geese flying from the roosts at sites Östen (No. 2, Appendix 1) and Tåkern (No. 21), and for counts of geese at feeding fields at the rest of the sites, were on a similar magnitude (making up 8-33 and $8-18 \%$ of the variance, respectively). The estimated variability in the number of Tundra Bean Geese among years contributed $4.8-7.3 \%$ of the total variance. This estimate is based on the assumption that on average 4000 Tundra Bean Geese were included in the counts (with a variability of $\pm 20 \%$ among years). The uncertainty in the total number of Bean Geese related to the number remaining at wintering grounds in southernmost Sweden and Denmark, as well as to geese reaching Norway and Finland are expected to be small and not contribute significantly to the errors calculated by equation (1).

The calculated Chi-square sum of 14.15 , equation (2), exceeded the $\chi^{2}(\mathrm{p}<0.05)$ significance level value of 14.07 when the expected count $\mu(t)$ was set to the average count of 52862 Bean Geese for the whole study period. This means that at 
least one out of the seven years significantly differed from the average for the study period. Pairwise comparisons of the quotient $(S(t)-\mu(t)) / \sigma(t)$ between years revealed that the 2015 count was significantly higher than counts made in 2011 and 2012 (test quantities of 3.68 and 3.55, for the two pairwise comparisons, respectively, $\mathrm{p}<0.05$ ). Also the number of 57000 in 2007 was close to significantly different from the number 47400 in 2012 (test quantity $3.20, \mathrm{p}<0.055$ for the comparison between 2007 and 2012).

Thus it is suggested that the population size of Bean Geese increased significantly $(p<0.05)$ from 2012 to 2015, following upon a close to significant decrease from 2007 to 2012. As noted from data in Table 1, there was no correlation between total numbers a specific year and the number of geese remaining at wintering grounds, nor with the number of geese already reaching staging sites in Finland or with the date of count. Neither was there any clear difference in the relative distribution of geese among staging sites (Appendix 1) for years with high and low counts. Thus, differences in numbers among years do not seem to relate to differences in the timing of migration (due to weather conditions) or any other factors related to the technical aspects of the counts.

The decrease in numbers between the level of 56 000 obtained the first two years (2007-2008) and the level of $\sim 48000$ for the period 2009-2012 may reflect a period with poor reproduction and/or high mortality. It is further noted that the increase from the repeatedly low numbers during the period 2009-2012 (three years with 47 000-49 000 geese can in fact be regarded as a sort of replication with small variance) 6000-7000 geese per year in both 2014 and 2015 may at least partly be linked to a decline in hunting pressure in Finland over the study period. The latter culminating with a hunting moratorium for Bean Goose effective in August 2014, an action included in the AEWA action plan (M. Alhainen, Finnish Wildlife Agency, pers. comm.). The reported annual Finnish hunting bag of Bean Geese (http://www.rktl.fi/www/ uploads/pdf/uudet $\% 20 j u l k a i s u t / T i l a s t o t / r k t l$ tilastoja 6_2014_metsastys_web.pdf) was estimated at a level of 5600-7900 for the period 2007-2009, followed by a slight decline from 5100 in 2010 to 3300 in 2013. In 2014 no Bean Geese were hunted. In Sweden there is so far no hunting moratorium and the hunting bag is estimated to have remained fairly stable during the period of the study (M. Alhainen, pers. comm.).
Contribution from Tundra Bean Geese in the counts

Counters were instructed to specify and count the geese by sub-species, but there were only single individuals or small groups of Tundra Bean Geese reported, totalling maximum 200 individuals any year. Maximum 140 was counted in a flock at site No. 20 (Mörlundaslätten), which is a site regularly hosting flocks of this magnitude. The tundra subspecies is at the majority of Swedish spring staging sites observed as single birds, pairs or small groups mixed into larger flocks of Taiga Bean Geese. At most sites individuals of the tundra subspecies make up 1-4\% (authors personal observations) of all Bean Geese. At some specific sites, however, larger flocks of Tundra Bean Geese are regularly observed. With the help of neck-banding of a population of Tundra Bean Geese staging and moulting at the Varanger Peninsula in northern Norway, a major wintering area for Tundra Bean Geese, totalling maximum 5000 individuals in mild winters, was recently localised close to Kristianstad in NE Scania, Sweden (Heinicke \& de Jong 2013, Kampe-Persson 2014). Marked Tundra Bean Geese from this northern Scandinavian population have been shown to migrate along the western flyway (utilizing spring staging mainly in the Luleå and Umeå areas in northern Sweden) and are estimated to approximately 3000 individuals (Heinicke 2010, Skyllberg et al. 2013, de Jong et al. 2013). These geese are therefore expected to be included in the counts reported here. Flocks of these banded geese have mainly been observed during spring staging at the sites of Tåkern and Östen (de Jong et al. 2013), where flocks exceeding 500 Tundra Bean Geese are regularly reported by Swedish ornithologists (www.artportalen.se). Because both of these sites are counted during the flight from the night roost, the tundra subspecies was easily overlooked in the counts reported here.

In spring 2010-2012, totals of between 1145 and 3745 Tundra Bean Geese were reported from southern Sweden by Heinicke \& de Jong (2013), mainly at the sites Östen (No. 2), Tåkern (No. 21) and Kvismaren (No. 4). The possible contribution to spring counts from Tundra Bean Geese breeding further east (than the ones moulting at the Varanger Peninsula) is not known but it is indicated to be substantially smaller than from the northern Fennoscandian population, based on re-sightings of birds in Sweden neck-banded outside Scandinavia (Heinicke \& de Jong 2013). In the error estimations (equation 1) it was assumed that on average 4000 Tundra Bean Geese were present at spring 
staging sites in Sweden and that the variability among years amounted to \pm 1000 individuals. Given that the population utilizing the western flyway is estimated at $\sim 3000$ birds, 1000 individuals are assumed associated with a variable influx from breeding area further east and possibly utilizing the central flyway in spring. It has been shown that absolute numbers and the variability of Tundra Bean Geese is largest during autumn (Kampe-Persson 2011, 2014, Heinicke \& de Jong 2013). Maximum 9150 Tundra Bean Geese were reported at staging sites in south Sweden in October 2009 (Heinicke \& de Jong 2013). It is therefore suggested that many of the additional Tundra Bean Geese reaching Sweden in autumn are wind-drifted from the east and that most of these are expected to take the route east of the Baltic Sea in spring, once they in mid-winter have reached their regular wintering grounds in Germany, in essence making a loop migration.

\section{Estimated number of Taiga Bean Geese migrating west and east of the Baltic Sea}

To estimate the total numbers of Taiga Bean Geese utilizing the western and central flyways in their migration west of the Baltic Sea, some further details need to be discussed in regard to the groups of Taiga Bean Geese wintering in the UK and in NW Jutland. Up to 400 Taiga Bean Geese wintering in Scotland (Musgrove et al. 2011) migrate via NW Jutland, where they stage in spring until they continue via southern Norway (Oslo area) and SW Sweden (lake Brosjön, in the county of Värmland) to their breeding grounds in the county of Dalarna, Sweden. (http://scotlandsbeangeese. wikispaces.com). As reported on this web-site, these geese normally have an earlier schedule in autumn and later in spring (residing at their staging sites in Denmark) than the majority of Bean Geese migrating along the western and central flyways. During the period 2007-2015 they left Scotland for Denmark well before the spring counts in Sweden, but GPS and neck-banded geese showed (in 2014 and 2015) that they stayed in Denmark and did not reach Norway and Sweden until the spring counts reported here were finished. Therefore this small population of Taiga Bean Geese is expected not to be included in the Swedish spring staging counts any of the years 2007-2015.

Another group of Taiga Bean Geese spend the winter in NW Jutland (in the Thisted-Thy area marked grey in Figure 1). These geese, totalling approximately 1200 individuals, breed at least partly in Nord-Trøndelag (Norway) and in the counties of Jämtland, Västerbotten and southern Lapland in Sweden, in accordance with some old (Parslow-Otsu 1991) and more recent neck-band studies (J.E. Østnes, pers. comm.). The migration schedule and flyway of this wintering population is not well-documented, but provided they have a similarly late schedule as the Taiga Bean Geese wintering in the UK and utilizing the same area in NW Jutland, it is suggested these birds were still remaining at the Danish sites in the Thisted-Thy area at the dates of the spring counts reported here. The number of geese reported from staging sites in Norway and at wintering grounds in Denmark during the dates of spring counts varied between 180 and 820 (Table 1). Few of these observations were from NE Jutland, where in essence all of the 1500 wintering Bean Geese had left for spring staging sites in Sweden at the date of counts (T. Brandt, pers. comm.). Thus, it is expected that observations in Denmark and Norway represent Taiga Bean Geese wintering in UK and NW Jutland.

A final estimate of the population of Taiga Bean Geese staging in southern Sweden in spring and migrating west of the Baltic Proper is reached by subtracting from the total an estimated number of 4000 Tundra Bean Geese. Furthermore, the discrepancy between an expected 1400 Taiga Bean Geese occupying mainly NW Jutland sites and the number of geese actually reported at Norwegian and Danish sites at dates of counts needs to be corrected for. Thus the difference between 1400 and the number of geese reported at Norwegian and Danish sites in Table 1 were added to the total. With these corrections and rounding off to the nearest hundreds, the number of individuals belonging to Taiga Bean Goose populations migrating west of the Baltic Sea during the period 2007-2015 amounted to 54000 (2007), 52600 (2008), 45900 (2009), 44200 (2011), 44200 (2012), 50900 (2014) and 57500 (2015).

The reported spring counts from this study are expected to make up the major part of the current estimate of the global population of the Taiga Bean Goose. A recent compilation of counts conducted in January at sites in Poland and eastern Germany implies a dramatic decline in the number of Taiga Bean Geese in recent years: 41600 (2005), 24000 (2009), 13900 (2011), 13200 (2013), 10700 (2015) (Heinicke et al., in press). In late autumn 2007 a total of 35000 were counted in the same area (L. van den Bergh, pers. comm.). If these numbers are taken as total estimates of birds migrating east of the Baltic Sea, and are added to the spring counts 
reported here, the global population of the Taiga Bean Goose is estimated at 89000 (2007), 69900 (2009), 58100 (2011), 68200 (2015). These numbers may be compared with previously reported estimates of the world population of 63000 individuals from 2007/2008 (Fox et al. 2010) and the latest population estimate from 2012 by Wetlands International (http://wpe.wetlands.org) amounting to only $40000-45000$ individuals. The basis for these two estimates was not specified. Given the information from this study and Heinicke et al (in press), they can both be considered underestimates for the years $2007 / 2008$ and 2012, respectively. I suggest the number of 68000 in 2015 should be regarded the current most reliable estimate of the Taiga Bean Goose world population.

Given the large fluctuations in the numbers of Taiga Bean Geese over a period of just a few years, as reported in this study, the population seems to be under large pressure and can be regarded very susceptible to changes in reproduction and mortality. Therefore it is of utmost importance that the AEWA action plan sustain and extend the existing hunting moratorium, and that the result of actions taken are followed up, until a sufficiently large and stable population of the Taiga Bean Goose has been established.

\section{Acknowledgements}

The author would like to thank a large number of ornithologists for organizing, conducting, quality assuring, summarizing and reporting counts of Bean Geese. Coordinators: Martin Tjernberg and Lars Bern (Uppland), Kent Halttunen (NärkeTysslingen), Magnus Friberg and Ragnar Edberg (Kvismaren), Kent-Ove Hvass and Edvin Klein (Östen), Tommy Petterson (Skåraområdet), Lars Gezelius (Tåkern), Ronny Johansson (AlvestaVäxjö). Out of numerous counters, the following made particularly important contributions: Ulf Hultinger (Gästrikland), Berndt Söderlund (Dalarna-Västmanland), Pekka Westin, Ulric Lötberg, Joakim Djerf, Elisabeth Djerf, Thomas Pless, Kenneth Pless, Tommy Eriksson, Anders Eriksson, Mats Edholm, Brita Tibell, Mats Wilhelm, Tom Norling, Åke Österberg and Per Johan Ulfendahl (Uppland), Marcus Rhenberg, Daniel Green, Jan-Erik Malmstigen, Jörgen Lindberg, Ralf Lundmark, Kalle Källebrink, Eva Johansson, Pentti J. Tatti, Ulf Carlson and Sven-Olof Eriksson, Sören Larsson (Västmanland), Ulf T Carlsson (Värmland), Tage Carlsson, Lage Johnson, Johan Åhlén, Ola Åhlén and Ola Strand (Närke), Lil- lemor Däckfors, Joackim Strengbom (Södermanland), Ulf Larsson, Peter Berglin, Robert Petersen (Östergötland), Calle Ljungberg, Niclas Strömberg and Stefan Andersson (Småland). Anders Muszta at the Swedish University of Agricultural Sciences is acknowledged for his valuable help with designing appropriate statistical tests. I also would like to thank Anthony Fox for constructive comments on the manuscript and for results in the progress of being published.

\section{References}

Fox, T., Ebbinge, B.S., Mitchell, C., Heinicke, T., Aarvak, T., Colhoun, K., Clausen, P., Dereliev, S., Farago, S., Koffibjerg, K., Kruckenberg, H., Loonen, M.J.J.E., Madsen, J., Mooij, J., Musil, P., Nilsson, L., Pihl, S. \& van der Juegd, H. 2010. Current estimates of goose populations sizes in western Europe, a gap analysis and assessment of trends. Ornis Svecica 20: 115-127.

Heinicke, T. 2010. Tundra bean goose Anser fabalis rossicus during spring migration in northern Sweden - rare visitor or regular passage migrant? Ornis Svecica 20: 174-183.

Heinicke, T. \& de Jong, A. 2013. Tundra Bean Geese Anser fabalis rossicus in central and southern Sweden autumn 2009-spring 2012. Ornis Norwegica 36: 32-37.

Heinicke, T., Fox, A.D. \& de Jong, A. In Press. A1 Western Taiga Bean Goose Anser fabalis fabalis. In Status and trends of Arctic and northern hemisphere goose populations - a global audit. Conservation of arctic Flora and Fauna Monitoring Report (Fox, A.D. and Leafloor, J.O., eds.) CAFF International Secretariat, Aukureyri, Iceland.

de Jong, A., Heinicke, T., Aarvak, T. \& Øien, I.J. 2013. Movements of Tundra Bean Goose Anser fabalis rossicus neck-banded in northern Scandinavia. Ornis Norwegica 36: 28-31.

Kampe-Persson, H. 2011. How large proportion of the Bean Geese counted in Sweden was made up of Taiga Bean Geese Anser fabalis fabalis. Ornis Svecica 21: 58-60.

Kampe-Persson, H. 2014. Staging and wintering Taiga Bean Geese Anser fabalis fabalis in north-east Scania, south Sweden. Ornis Svecica 24: 56-78.

Musgrove, A.J., Austin, G.E., Hearn, R.D., Holt, C.A., Stroud, D.A. \& Wotton, S.R. 2011. Overwinter population estimates of British waterbirds. British Birds 104: 364-397.

Nilsson, L. 2011. The migrations of Finnish Bean Geese Anser fabalis in 1978-2011. Ornis Svecica 21: 157-166.

Nilsson, L. 2013. Censuses of autumn migration of staging and wintering goose populations in Sweden 1977/1978 2011/2012. Ornis Svecica 23: 3-45.

Nilsson, L., van den Bergh, L., \& Madsen, J. 1999. Taiga Bean Goose (Anserf. fabalis). Pp. 20-36 in Goose populations of the Western Paleractic. A review of status and distribution (Madsen, J., Cracknell, G.S., \& Fox, A.D., eds.) Wetlands International Publications No. 48, 20-36.

Nilsson, L., de Jong, A., Heinicke, T., \& Sjöberg, K. 2010. Satellite tracking of Bean Geese Anser fabalis fabalis and Anser fabalis rossicus from staging areas in northern Sweden to breeding and moulting areas. Ornis Svecica 20: 184-189. 
Nilsson, L., \& Pirkola, M.K. 1991. Migration pattern of Finnish Bean Geese Anser fabalis. Ornis Svecica 1: 81-92.

Nordjyllands Fugle 2013. Foreningen Nordjyllands Fugle. www.nordjyllandsfugle.dk

Nordjyllands Fugle 2014. Foreningen Nordjyllands Fugle. www.nordjyllandsfugle.dk

Parslow-Otsu, M. 1991. Bean Geese in the Yare Valley, Norfolk. British Birds 84: 161-170.

Pessa, J., Väyrynen, E. \& Timonen, S. 2004. Metsähanhitutkimuksen ja -seurannan tuloksia kolmen vuosikymmen ajalta. English Summary: The results of three decades of research and monitoring studies of the Finnish Bean Goose population. Linnut-Vuosikirja 2004: 28-33.

Skyllberg, U., Hansson, P., Andersson, Ö., Bernhardtson, P., Gustafsson, R., Laisfeldt, M., Naudot, E., \& Nordlund, M. 2008. Spring staging, flyways and population estimate of the northern Scandinavian taiga Bean Goose Anser f. fabalis 2002-2006. Vogelwelt 129: 253-262.

Samuels, M., Witmer, J., \& Schaffner, A. 2014. Statistics for the Life Sciences (4th Edition), Pearson Education.

Skyllberg, U., \& Tjernberg, M. 2008. Spring staging of Taiga Bean Goose (Anser f. fabalis) in southern Sweden 2007 estimate of the size of populations using the western and central flyway. Ornis Svecica 18: 45-51.

Skyllberg, U., Nousiainen, N., Hansson, P., Bernhardtson, P., Andersson, Ö., \& Nordlund, M. 2009. Spring migration of the Taiga Bean Goose Anser f. fabalis along the "Western Flyway" in northern Sweden: numbers in 2003-2008 and timing in comparison with the "Central Flyway" in western Finland. Ornis Svecica 19: 199-214.

Skyllberg, U., Bernhardtson, P., Naudot, E. \& Hansson, P. 2013. Taigasägås (Anser f. fabalis) och tundrasädgås ( $A$. f. rossicus) rastande $\mathrm{i}$ Umedeltat och Brånsjön vårarna 2007-2012: Dagsmaxnoteringar i relation till övriga Västerbotten och Norrbotten. Fåglar $i$ Västerbotten 38: 8-15.

\section{Sammanfattning}

Tajgasädgåsen Anser f. fabalis häckar i den nordligt boreala zonen från Skandinavien till centrala Ryssland. Världspopulationen har minskat de senaste decennierna. I slutet av 1990-talet uppgavs världspopulationen omfatta $90000-110000$ individer. Nuvarande populationsuppskattningar hamnar på 63000 individer (Fox m fl. 2010) eller 40 000-45 000 individer (Wetlands International, 2012). Med anledning av den snabba populationsminskningen lanserade organisationen AEWA (Agreement on the Conservation of African-Eurasian Migratory Waterbirds) ett artspecifikt åtgärdsprogram för tajgasädgåsen 2013. På agendan finns önskemål om bättre grundade populationsuppskattningar. Här redovisar jag årliga populationsuppskattningar av tajgasädgäss som sträcker längs den västra och centrala flyttvägen genom Sverige på våren. Baserat på dessa räkningar redovisas även en skattning av världspopulationen.

\section{Material och Metoder}

I denna studie rapporteras räkningar av sädgäss på 44 vårrastlokaler i södra Sverige för åren 20072015. Under perioden kunde räkningar med god kvalité utföras sju av nio år $(2007,2008,2009$, 2011, 2012, 2014, 2015). Vårarna 2010 och 2013 var mycket sena och väderbetingelserna gjorde att felkällorna blev för stora. Resultaten för 2007 har tidigare rapporterats (Skyllberg \& Tjernberg 2008). Räkningarna omfattar samtliga kända rastplatser för sädgäss i södra Sverige (Figur 2 och Appendix 1), samt kvarvarande sädgäss på övervintringslokaler i Sydsverige (Skåne) och Danmark. Räkningarna utfördes under ett begränsat tidsfönster i mars då sädgässen lämnat sina vinterkvarter i Skottland, Danmark och Sydsverige för att rasta inom ett begränsat område i norra Götaland och Svealand, men innan de i nämnvärd omfattning flyttat vidare till Norge och Finland. Principen för detta illustreras i Figur 3 för våren 2015. Räkningarna utfördes samtidigt på alla lokaler under några dagars tid, ofta några dagar efter en omfattande flyttningsrörelse men innan nästa rörelse utlöstes. Gässen är speciellt obenägna att röra sig mellan rastlokaler under perioder med vindar från N-sektorn (motvind) samt i samband med nederbörd. Avsaknad av flyttningsrörelser under räkningsdagarna konfirmerades $\mathrm{m}$ h a data från Artportalen (www.artportalen.se). Varje lokal hade en kontaktperson som sammanställde observationerna inom området och rapporterade till författaren. På de större rastplatserna vid Östen och Tåkern räknades gässen vid utflog från nattplatsen. På övriga lokaler räknades gässen under födosök dagtid.

För att statistiskt kunna testa om skillnader i antalet gäss mellan åren berodde på osäkerheter i räkningarna eller om antalet gäss varierade över tid, så beräknades ett totalt fel för räkningarna m $\mathrm{h}$ a ekvation (1). Felen för räkningarna vid utflog från nattplatserna i Östen och Tåkern uppskattades till $\pm 15 \%$. Felet vid räkningar av födosökande sädgäss på övriga rastplatser bedömdes vara betydligt lägre $( \pm 3 \%$.). Antalet tundrasädgäss i räkningarna skattades till i medeltal 4000 , och dess variation mellan år till $\pm 20 \%$. Slutligen uppskattades felen orsakat av dubbelräkningar av gäss på flera lokaler samt gäss som missades då de var i aktiv flykt mellan lokaler att delvis uppväga varandra, men ändå kunna bidra till $\pm 5 \%$. Med ekvation (1) beräknades så det absoluta felet för varje år. Ett statistiskt test utfördes $\mathrm{m}$ h a ekvation (2), där felet: $\sigma(\mathrm{ti})$ beräknat för ett visst år sattes i relation till avvikelsen mellan det räknade antalet sädgäss: $\mathrm{S}(\mathrm{ti})$ och det 
förväntade antalet sädgäss: $\mu(\mathrm{ti})$. Det senare sattes lika med medelvärdet för de sju åren: 52862 .

\section{Resultat och diskussion}

I tabell 1 redovisas räkningarna för vart och ett av de sju åren. Förutom antalet sädgäss på de svenska vårrastlokalerna redovisas också sädgäss som under räkningstillfället dröjde sig kvar i övervintringsområdet i Skåne eller Danmark, samt gäss som nått rastplatser i Norge och Finland. Den generella trenden under studieperioden var en minskning av gäss från en högre nivå 2007-2008 (57 000 respektive 55400 ) till en lägre nivå om 46 900-49 300 gäss 2009-2012, sedan avslutningsvis en uppgång till 53900 (2014) och till 60200 (2015). Enligt felberäkningen varierade osäkerheten i räkningarna mellan \pm 2900 sädgäss 2012 och \pm 3600 (2008 och 2015), vilket motsvarade $6.0-7.5 \%$ av de räknade antalen. Ett beräknat Chi-square test påvisade signifikanta skillnader mellan år $(\mathrm{p}<0.05)$. Parvisa jämförelser av enskilda år visade att skillnaden mellan 2015 års data $(60215)$ samt data från 2011 (46 930) och 2012 (47 395) var signifikant skilda, och att antalet 2007 (57 000) var nästan signifikant skilt från 2012.

Baserat på de statistiska testen så föreslås att tajgasädgåsen ökade i antal från 2011 och 2012 till 2015, efter det att den minskat mellan perioden 2007-2008 och 2009-2012. Minskningen kan rimligen förklaras av en försämrad reproduktion eller förhöjd mortalitet, eller en kombination av båda. Ökningen föreslås bero, i alla fall delvis, av det minskade jakttrycket i Finland. Enligt officiell jaktstatistik sköts under perioden 2007-2009 årligen mellan 5600 och 7900 sädgäss i Finland. Antalet minskade sedan till 5100 under 2010 och 3300 under 2013. På inrådan av AEWA infördes 2014 ett förbud för jakt av sädgås i Finland. Rimligen bör den tydliga uppgången från 2012 till 2014 och 2015 kunna sättas i samband med en minskad mortalitet i Finland. I Sverige finns ingen information som tyder på någon minskad avskjutning under samma period.

Märkning med halsband, GPS sändare och systematiska observationer har under den senaste femårsperioden avslöjat en mindre population av tundrasädgäss som häckar i nordligaste Skandinavien (och angränsande områden på Kolahalvön), ruggar på Varangerhalvön och som övervintrar inom ett begränsat områden i nordöstra Skåne. Mellan 1145 och 3745 tundrasädgäss räknades under vårrastningen i södra Sverige (främst Östen, Kvismaren och Tåkern) 2010-2012. Populationen, som utnyttjar rastlokaler längs den västra flyttvägen genom Sverige och kan förväntas ingå i våra räkningar, skattas i nuläget till ca 4000 individer. Det faktum att endast ca 200 tundrasädgäss räknades per år på rastlokalerna i denna studie, kan åtminstone delvis förklaras med att merparten av tundrasädgäss ur den "Nordskandinaviska" populationen framförallt rastar vid Östen och Tåkern, där räkningarna utfördes under utflog på morgonen. Så det är förståeligt om tundrasädgåsen förbisågs på dessa två lokaler.

För att erhålla en skattning av det totala antalet tajgasädgäss som utnyttjar den västra och centrala flyttvägen genom Sverige subtraherades från årssummorna i Tabell 1 det uppskattade antalet om 4000 tundrasädgäss. Dessutom beaktades att samtliga av de 1400 sädgäss som övervintrar i Skottland och på NV Jylland, och som förväntas sträcka vidare till häckområdena i Dalarna och i gränstrakterna av Mellansverige och Norge, sannolikt inte inkluderats fullt ut i räkningarna. Således adderades skillnaden mellan 1400 och summan av antalet sädgäss som räknades i Norge och Danmark (i Tabell 1). Efter denna korrigering erhölls årliga skattningar om 54000 (2007), 52600 (2008), 45900 (2009), 44200 (2011), 44200 (2012), 50900 (2014) och 57500 (2015) tajgasädgås som utnyttjade rastlokaler väster om Östersjön under vårsträcket perioden 2007-2015. Världspopulationen av tajgasädgås skattades sedan genom att till summan väster om Östersjön lägga till det antal tajgasädgäss som räknades på övervintringsplatser i Tyskland och Polen under samma period (Heinicke et al., in press), vilket resulterade i totalsumman 89000 (2007), 69900 (2009), 58100 (2011), 68200 (2015). Min uppfattning är att dessa antal utgör de bästa tillgängliga skattningarna av tajgasädgåsens världspopulation och populationsutveckling under de senaste nio åren. Det betyder att Wetlands Internationals officiella notering om 40 000-45 000 individer snarast bör uppdateras. Med tanke på de kraftiga kortsiktiga fluktuationer som tajgasädgåsen uppvisar så bör ett moratorium för jakt upprätthållas och utökas till flera länder än Finland för att säkerställa en positiv utveckling av beståndet till en högre och mer stabil nivå. 


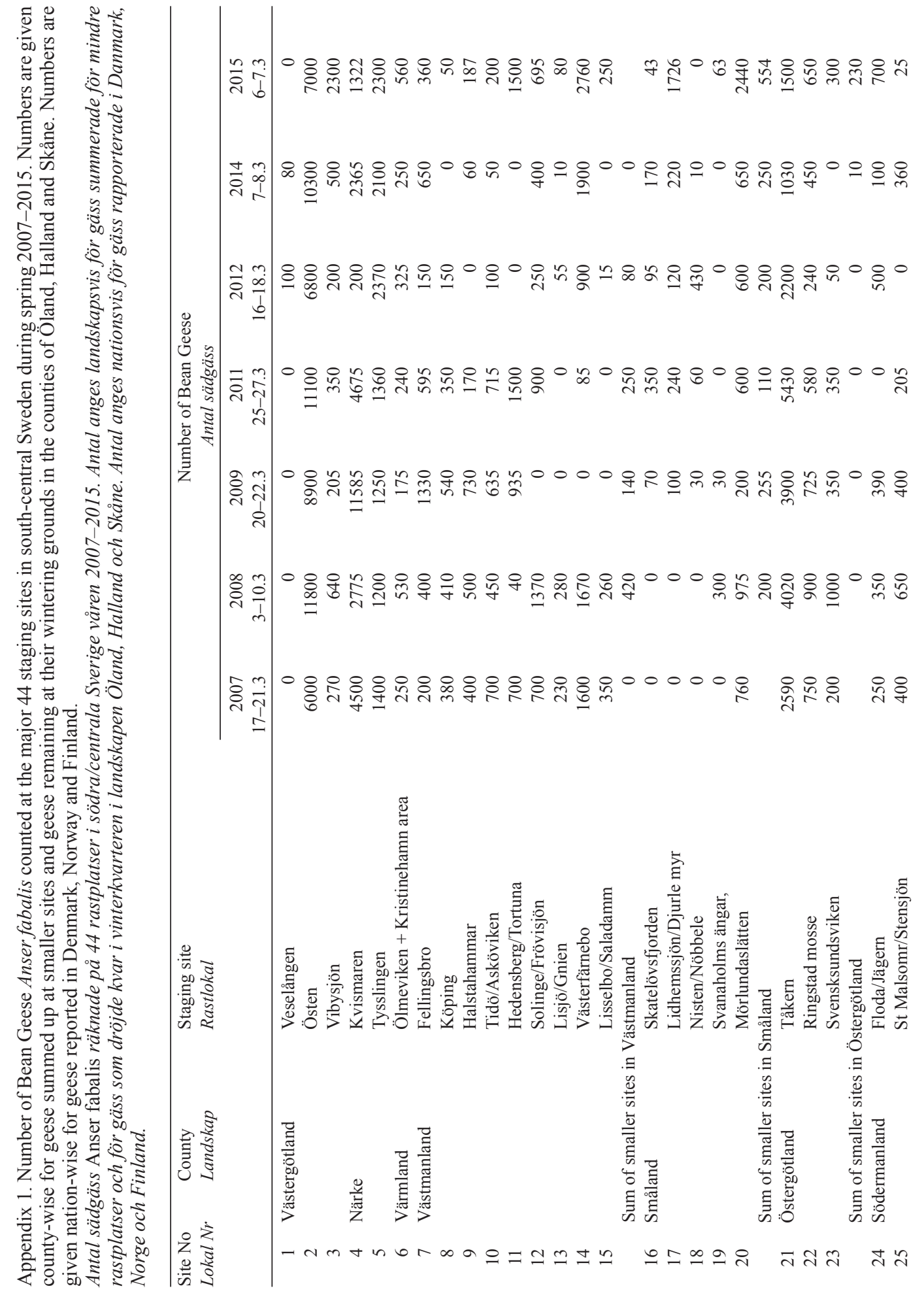




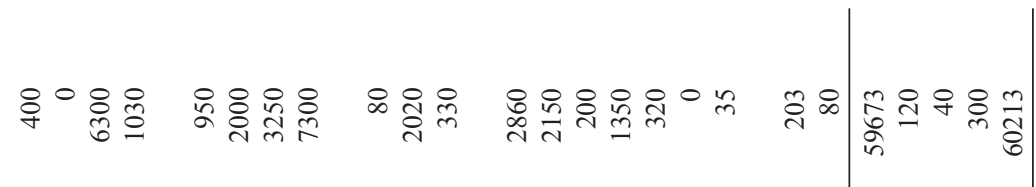

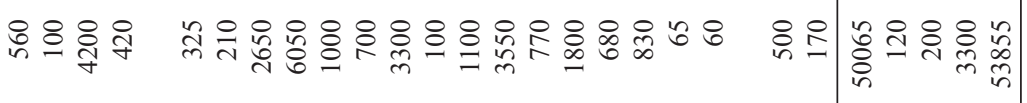

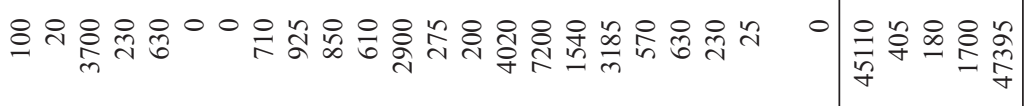

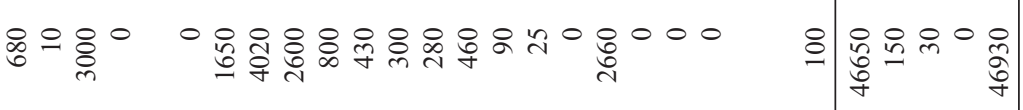

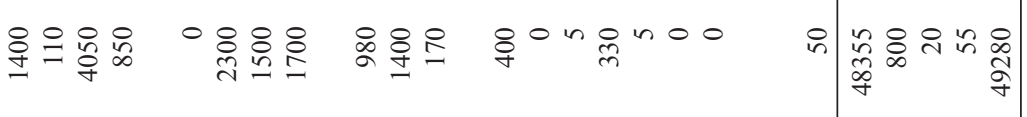

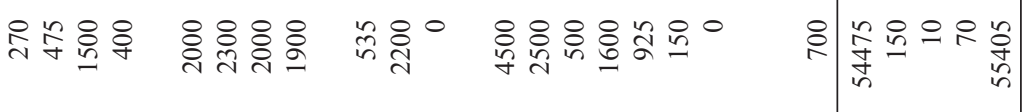

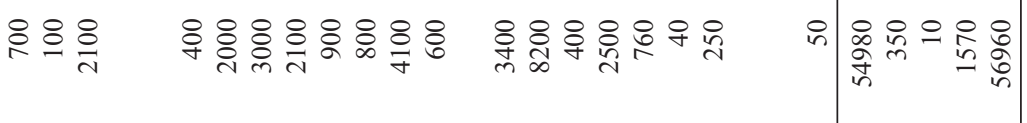

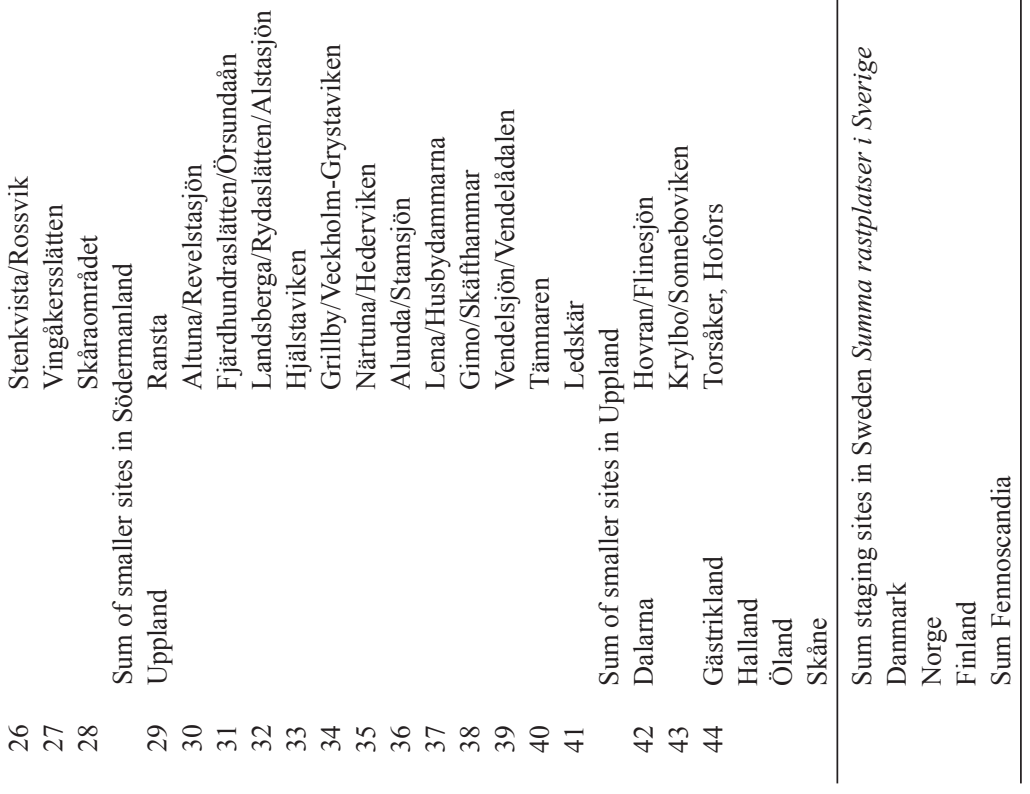

